\title{
АРХЕТИП І СИМВОЛ У ПОЕЗІЇ ВІРИ ВОВК
}

У статті розглянуто деякі особливості художньої інтерпретаиії архетипів і символів у поезії Віри Вовк. Одним із джерел конщептосфери письменниці $\epsilon$ традиційні метаобрази європейської культури, зокрема християнські символи, які органічно поєднуються із образними константами украӥнської народної творчості. Ці наскрізні мотиви лежать в основі загальної структури метаобразів поезії Віри Вовк $i \in$ маркерами найвиразніших рис їі ідіостилю. Розглянуті крізь призму конщептуального аналізу різні за мірою узагальнення символи визначають основні характеристики художньої картини світу, щуо постає в ліриці Віри Вовк.

Ключові слова: архетип, символ, конщепт, конщептуальний аналіз, художня картина світу.

Поезія Віри Вовк у своїй сукупності становить цілісну мистецьку будову, в основі якої лежить система метаобразів, концептуальних метафор i символів, які розгортаються в окремих віршах, циклах і збірках в оригінальні послідовні мотиви. Метою нашої розвідки є концептуальний аналіз деяких метаобразів поезії Віри Вовк, що дає ключ до глибшого розуміння природи ідіостилю письменниці, його органічних зв'язків зі світовим мистецьким процесом і українською літературною традицією. Основними завданнями статті $є$ розкриття специфіки концептуальних метафор письменниці, їхньої ієрархічної структури і ключової ролі у формуванні іiї художнього світу.

Окремі аспекти індивідуального стилю письменниці та особливості поетики іï творів проаналізовано в численних розвідках українських науковців (Т. Антонюк, О. Астаф'єв, А. Біла, Ю. Григорчук, Н. Грицик, I. Жодані, М. Ковінько, І. Котик, Б. Рубчак, Т. Остапчук, О. Смольницька та ін.), проте єдність художнього всесвіту поетеси, наскрізні мотиви метатексту іiї поезії, ієрархічна структура знакових метафор і символів залишаються поза увагою дослідників. Ми спираємось на концепцію інтерсеміотичності творчості Віри Вовк, обгрунтовану в дисертації Ірини Жодані [6], характеристику стильової течії сюрреалізму в українській поезії ХX ст., запропоновану в дослідженні Тетяни Антонюк [1], а також на теоретичні принципи концептуального аналізу художнього образу, розроблені у працях В.Г. Зусмана [12], В.І. Карасика [13], В.М. Телія [17], І.В. Толочина [17] та ін.

У ліриці Віри Вовк знайшли відображення численні архетипи і символи, які складають «кістяк» металогічної образної структури іiї поезії. Вони формують базис поетичної світобудови, духовну характеристику ліричного героя і визначають основне поле його діяльності, світ уявлень, переживань і почувань. Архетипи реалізуються в двох типах образних структур: символах i міфах. Якщо процесуальною категорією тут виступає міф, який є сюжетною історією виникнення символу, то сам символ виступає статичним поняттям, у 
якому відчитується відразу і весь процес його міфологічного становлення, $\mathrm{i}$ кожен його момент одночасно. Серед архетипних символів найголовнішими $\epsilon$ «космогонічні» символи триєдиної світобудови, раю/пекла, життя/смерті (сну), ініціації як переходу з одного пограничного стану до іншого. На такому пігрунті створювалася будь-яка міфологічна система, зокрема й мистецька. Специфічно інтерпретовані архетипні символи лежать в основі художніх систем сюрреалізму та символізму, які є визначальними для поезіі Віри Вовк.

Для аналізу металогічної образності лірики поетеси ми обрали концептуальний аналіз. Кожен концепт представляється у вигляді асоціативного поля, а в поетичному він виступає як основа, що потенційно містить варіанти асоціативного розгортання змісту. При цьому ми спираємося на прийом інтерпретації змісту концептів із залученням життєвого досвіду автора і уявного читача.

Форму архетипу Юнг порівнював із кристалічною решіткою, яка означує матеріальну структуру кристалу: «Архетип сам собою “порожній” і суто формальний, це лише можливість існування, здатність до виявлення того, що дано a priori. Уявлення як такі не успадковуються, вони - лише форма» [19, 10]. Аби архетип став архетипним образом, необхідне його осмислення, індивідуальний досвід людини, він повинен зазнати оригінальної свідомої обробки. «Потім такі індивідуальні, нерідко спонтанні, утворення включаються у сукупність феноменів суспільної свідомості та через набуття значення і сенсу стають колективними формами - символами» $[14,7]$. Власне символ є кінцевою ланкою еволюції образу, мірою його максимального узагальнення. Ми можемо стверджувати, що архетипи як вроджені формальні структури колективного підсвідомого, найповніше і найчастіше виявляються у символах, а виходячи за межі етнічного та національного буття, становлять основу загальнолюдської символіки.

Важливу конструктивну роль у концептосфері поезії Віри Вовк відіграють базові символи, які у працях сучасних дослідників мають різні назви, проте спільну конституційну ознаку: вони становлять фундамент художньої картини світу митця. Т.Гундорова називає їх «знаками-симптомами», «знаками-сигналами» [10, 14], О.Бистрова - «ключовими символами», «образами-домінантами» [Див.: 2], Л.Петрухіна - «маркерами», «символамиключами» [Див.: 16]. Система металогічних образів поезії Віри Вовк базується на поєднанні в іiі творчості декількох різнорідних парадигм. Більшість подібних образів мають загальнокультурне походження, відбивають етнічно марковані світоглядні універсалії.

Особливе значення для поезії Віри Вовк мають етнічні маркери української символіки. У ранніх збірках це лише окремі натяки, спорадичні метафори, розчинені в ліричному міркуванні пейзажної чи медитативної лірики:

За топірцем манджає білий день,

I ніч готує знов зірок макітру.

Весняні труби засурмили; йде 
Моя весна назустріч вітру.

Зостався - там - чічками битий плай

I чорний бір, що витканий казками, -

Шукаю вишивкового тепла;

Тулю до серця сірий камінь.

Етнічні маркери (чічка, плай, ткання, вишивка, тин) єднаються в фіналі вірша символічним образом «пісні срібної»:

Новий вже обрій хилиться, мов тин,

Нові шляхи мені сміються дрібно.

Я скарб взяла з собою лиш один:

Глибоко в грудях пісню срібну.

(«Срібна пісня», зб. «Зоря провідна», 1955).

Подібний алюзивний характер має етнічна символіка в поезії «Орхідеї»:

Де мій запашний чорнозем, де лимани,

Що купали б моє коріння?

Де дерва, що піднесли б галуззя, як ліри?

Де журавлі, що перевезли б

Мою тугу за далекі моря?

(Зб. «Елегії», 1956)

У вірші «Тореадори і герої» Віра Вовк звертається до героїв, порівнюючи їхні подвиги з безглуздою жорстокістю тореадорів, що прийшли на зміну високому смислу героїчного діяння. При цьому використовує глибокий питомо український символічний образ Марка Проклятого:

Горе нам, винним завжди! Несемо

Ярмо Марка Проклятого жорнами

На зболілій душі, хижаки з насолоди.

(Зб. «Елегії», 1956)

Етнічний символ тут $є$ прозорою алюзією на християнський символ Христа, що несе свій хрест на Голгофу. Цей символічний мотив має й інші образні конотації у збірці «Елегії»:

Кожен несе своє горе, як слимак шкаралющу

(«Орхідеї»).

Символічний образ Марка Проклятого набуває розвитку в наступній збірці «Чорні акації» (1961), де йому присвячено однойменний вірш. Із образної цитації він набуває ролі авторської інтерпретації, змінює свою художню функцію:

Дорога й дорога!

Пил континентів

В'ївся в облич борозни,

Хтось плакав, і виросло море. 
А дзвони жайворонків - перелітні,

I сонце на дзвіниці,

Й веснянка в гаї.

...Чужий усьому.

Неси ж собі холодний біль

По всіх підсоннях,

Бери красу, впивайся вітром,

Несите серце,

Самотнє серце,

Прокляте.

Етнічно марковані символи - лише один із елементів художньої картини світу в ліриці Віри Вовк. Наведена зміна мистецького трактування народної легенди про Марка Проклятого ілюструє загальну еволюцію використання символіки в творчості поетеси.

Символ Марка Проклятого резонує своїм змістом зі становищем поетеси на еміграції: герой народної поезії мандрував до пекла, у потойбічний світ, долаючи помежів'я між світами - так само авторка опинилася за межею рідної землі, за океаном. Перехід, подолання грані між світами конституційна риса ініціаціï, одного 3 ключових моментів міфології, що породив цілу низку світових культурних символів.

Закономірним у контексті зацікавлень Віри Вовк неосимволізмом $\epsilon$ звернення поетеси до образу сну як продукту підсвідомості. Сон - символ тимчасового забуття. Саме у сні розум та логіка втрачають контроль над свідомістю, поступаючись місцем субстрату думок, ідей, почуттів і відчуттів. У ліриці Віри Вовк цей символічний мотив одержує своєрідну художню інтерпретацію. Він варіюється в багатьох творах поетеси, проте найцікавішим і показовим у плані суто авторського трактування типового сюрреалістичного мотиву, характерного саме для Віри Вовк, видається вірш «Сон у солом'яній кресані»:

Тільки мій сон

У солом'яній кресані

Блукає між буками,

Шукає Довбушевих скарбів

На горбі дерев'яного дому,

Ставить капличку з паперових іконок

В кущі порічок

Або нанизує на стебелину

Щире намисто суниць.

(Зб. «Писані кахлі», 1999).

Символи сну, смерті - суто модерністські за авторською інтерпретацією, яскраво передають домінантні суспільні настрої занепаду, відчуттяпередчуття кінця, руйнування, вмирання. Дослідниця символізму М.Моклиця пояснює особливу пристрасть людини межі століть до теми смерті тим, що 
лише смерть «звільняє людину від усіх матеріальних залежностей, може стати початком безсмертя, входом у світ духу» [15, 23].

Одним із найбільш частих символів у сновидіннях, котрі передають трансцендентне звільнення, $\epsilon$ мандрівка на самоті або паломництво, що перетворюється на духовні блукання, у яких посвячений ознайомлюється із сутністю смерті. Ця символіка може реалізовуватися не лише польотом птаха або мандрами у невідомі краї, але будь-яким сильним вчинком, який втілює це звільнення.

Характерним у цьому плані є вірш Віри Вовк із однієї з хронологічно пізніх збірок поетеси «Зеніт» (2012):

\author{
Я ходжу самотня по межі \\ між явою й уявою, \\ де сон стає дійсністю \\ а дійсність - маревом. \\ Лузаю день за днем, \\ як сім'я соняшника. \\ Язичницьку страдницю \\ треба в Дніпрі топити, \\ наче Марену. \\ Тільки тоді настане \\ час квітування та звивання \\ щасливих гнізд.
}

У ньому цілковито відсутнє питоме для сюрреалістів бунтівливе, героїчне начало, натомість етнічна символіка набуває надзвичайної значущості в плані вираження містичної глибини самовиявлення духовного світу ліричної героїні. Авторка підкреслює саме межовий стан між сном і дійсністю, «між явою й уявою», розширюючи цей своєрідний мотив ініціації інтертекстуальною алюзією на стародавній ритуал топлення відьом, на культ стражденного божества, що мусить загинути задля життя всього сущого.

Характерною сферою образності поезії Віри Вовк $є$ поетика міфу. Філософський сенс міфологічного мислення полягає у синкретичному погляді на буття, у глибинному відчутті єдності людини і природи, людини і всесвіту, взаємотрансформації всього сущого на землі. Для українського сюрреалізму найпитомішим тут виявився пантеїзм Б.-І.Антонича, творчість якого справила значний вплив на лірику Віри Вовк. Ідеться не про релігійні мотиви, які в ऑiі поезії посідають одне 3 почесних місць, а саме про пантеїстичну, сюрреалістичну символіку повноти буття, єдності всього сущого. Джерела цього філософсько-ліричного мотиву авторка шукає, подібно до метрів світового сюрреалізму, в архаїчних віруваннях екзотичних народів (напр., бразильському язичницькому культі богині моря Сманжу чи тибетських віруваннях у зб. «Мандаля»), проте найпродуктивнішим виявляється ii звернення до українських етнічних традицій. Мистецьке усвідомлення й художнє освоєння цього благодатного джерела приходить у зрілій творчості. Ось лише кілька прикладів зі збірки «Зеніт» (2012): 
Бог вибрав серце 3 грудей і мовив:

- Я зробив його язичницьким,

і тебе, як поганського ідола,

спалять на капищі.

А $з$ попелу

вигребуть глиняний глек,

про який я розказував самаритянці.

Я спитала: - Болітиме, Господи?

- Так, - відрік. - Але на глеку

я випалю кривим танцем

чорний узір.

У поетичній світобудові Віри Вовк «язичницький» мотив анітрохи не суперечить християнській символіці - навпаки, поєднується в органічне ціле під Всевишньою волею:

- А ще ти станеш ланню

в язичницькім міті,

сказав Бог.

- Ратищем воїн уб'є тебе,

але ти воскреснеш і станеш

безсмертною

в печернім малюнку.

Невеличкий, але надзвичайно місткий символічний цикл розвиває наступний вірш-молитва:

Коли мене палитимуть

на кострі, чи на капищі,

Господи, випали $з$ моїх костей,

моїх страстей,

моєї любови,

трипільську амфору,

або гуцульський дзбан

з візерунком барвінку довкола.

Такими само пантеїстичними нотами сповнене й продовження циклу, де вплетені етнічні народнопоетичні символи:

Та заки мене спалять

на кострі, чи на капищі,

заки втоплять Мареною

у хвилях Дніпра

ой, на Івана, та на Купала...

Нарешті завершується цикл своєрідною маніфестацією авторського credo:

Гібридними страстями 
нікому не треба журитися,

вони - тільки мої.

Погани - з чаклунством обізнані,

а християни звиклі на арені вмирати

від левів і глядіяторів.

У цих рядках - своєрідний підсумок творчої еволюції мотиву віри, який 3'являється ще в ранніх збірках поетеси, міцніє і стає домінантою в християнській символіці зрілої творчості і нарешті знаходить філософський синтез у визнанні святості як такої, віри як любові, що єднає архаїчні звичаї 3 надсучасними виявами Добра.

Одним із продуктивних джерел символіки у творчості Віри Вовк $є$ Театр і Карнавал з усіма їхніми атрибутами. Класична метафора «життя - театр» у ліриці поетеси розгортається в серію метафор, де символічний образ людиниактора набуває багатьох відмін. Одна 3 них - карнавал. Йому присвячений вірш «Баляда про маску на карнавалі» (зб. «Каппа хреста», 1969), у якому введено символічний масив, який згодом стане визначальним у художній картині світу лірики Віри Вовк: карнавалу, маски:

\author{
Я вишиваю щоночі \\ Маску на карнавал... \\ Щоб тільки раз у житті \\ Захлинутися щастям... \\ Хай потім скотиться сонце \\ В бездонну могилу \\ I черви хай точать його обличчя! \\ Мені байдуже! \\ Раз тільки, раз \\ Випити весь океан \\ I танцювати на бубнах \\ Під ворожбою зірок!
}

Згодом цей мотив знайде свою зрілу й багатогранну інтерпретацію у збірці «Жіночі маски» (1994), де збагатиться значно ширшим інтертекстом. Маска - один із ключових для творчості Віри Вовк образів-символів. Цей металогічний концепт формує своєрідну розімкнену параболічну структуру, яка надається до надзвичайно багатопланового відчитання.

Збірка «Жіночі маски» вражає високою поетичною майстерністю, умінням віртуозно й вишукано передавати внутрішнє відчуття світу, своє особисте бачення певних подій. Варто відзначити, що збірка становить органічну єдність - вона складається з 65 поезій: із 65 «масок»- символічних образів, які вибудовують цілісний образ Жінки.

Кожна «маска» - це символ окремої риси характеру, певної події або внутрішнього стану. Завдяки такій структурі авторка показує багатогранність ліричної героїні, відтворює їі минуле й накреслює майбутнє. Збірка постає не 
«сумою значень» окремих віршів-масок - у своїй сукупності поезії набувають надзвичайно глибокого, багатошарового, гіпертекстуального значення. Важливий добір окремих масок - вони є символічними для певної епохи, культури, знакового історичного моменту, вміщують не лише хрестоматійну «оболонку», завдяки якій стали називними, а й увесь комплекс свого буття. Віра Вовк знаходить ключ не лише до глибшого розкриття образу ліричної героїні, а й до зворотного впливу: повнішого осягнення «маски» - культурного символу.

Кожна «маска»є невід'ємною частиною збірки, невід'ємною деталлю, на основі яких, наче з пазлів, постає образ втраченої Батьківщини. Завдяки такому розмаїттю «масок» перед нами постає цілісний, багатогранний образ Жінки, ототожненої з Україною.

Використані протиставлення у програмовому вірші збірки «Жінка» передають багатоликість та своєрідність образу:

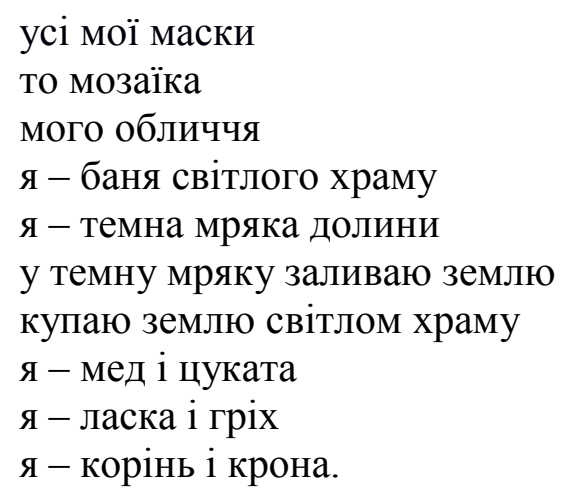

У збірці «Жіночі маски» простежується металогічний образ Жінки, створений за допомогою «масок»-символів. Він уособлює рідну землю, туга $\mathrm{i}$ вболівання за долю якої є наскрізною темою всієї творчості авторки.

Окреме місце в ліриці Віри Вовк посідають численні міфологічносимволічні образи світової культурної спадщини: Орфей, Евридика, Деметра, Єва, Пенелопа, Кассандра, Пентезілея та ін.

Отже, специфіка лірики Віри Вовк полягає в тому, що кожна ii збірка, кожен вірш стають окремими гранями єдиного цілісного явища, надтекстової єдності, пронизаної наскрізними мотивами, топосами, символами. Ця єдність еволюціонує, змінюється, набуває нових рис, але ніколи себе не заперечує. Основою ii виступають архетипні символічні образи, що визначають цілісність художньої картини світу, повноту розкриття духовного багатства ліричної героїні. У поезії Віри Вовк знайшли відображення численні архетипні символи, які складають «кістяк» металогічної образної структури іiі поезії. Вони формують базис поетичної світобудови, духовну характеристику ліричного героя і визначають основне поле його діяльності, світ уявлень, переживань i почувань. Архетипи реалізуються в двох типах образних структур: символах і міфах.

У творчості поетеси ми розглянули різні за мірою узагальнення символи архетипної природи, які визначають основні характеристики художньої 
картини світу, що постає в їі ліриці. Вони визначають найзагальніші смислові параметри тих надтекстових образних, структур, які об’єднують лірику Віри Вовк у нерозривне ціле.

\section{ЛIТЕРАТУРА}

1. Антонюк Т. Сюрреалізм як художній напрям в українській поезії XX століття (Е.Андієвська, Б.-І.Антонич, М.Воробйов, О.Зуєвський) / Тетяна Антонюк. - Автореф. дис. на здобуття наук. ст. канд. філол. наук. - Київ, 2004. -18 c.

2. Бистрова О. Формотворчі функції домінантних образів. На матеріалі української та російської поезії / Олена Бистрова. - Автореф. дис. на здобуття наук. ст. канд. філол. наук. - Київ, 2001. - 18 с.

3. Вовк В. Зеніт / Віра Вовк. - Львів: БаК, 2012. - 102 с.

4. Вовк В. Зоря провідна / Віра Вовк. - 1955.

5. Вовк В. Елегії / Віра Вовк. - 1959.

6. Вовк В. Жіночі маски / Віра Вовк. - 1994.

7. Вовк. В. Каппа хреста / Віра Вовк. -1969.

8. Вовк В. Писані кахлі / Віра Вовк. - 1999.

9. Вовк В. Чорні акації / Віра Вовк. - 1961.

10. Гундорова Т. ПроЯвлення слова. Дискурсія раннього українського модернізму. Постмодерна інтерпретація/ Тамара Гундорова. Львів: Центр гуманітарних досліджень Львівського державного університету ім. І.Франка, 1997. - 297 с.

11. Жодані I. Інтерсеміотичність у творчості письменників НьюЙоркської групи (Емма Андієвська і Віра Вовк) / Ірина Жодані. - Автореф. дис. на здобуття наук. ст. канд. філол. наук. - Київ, 2007. - 18 с.

12. Зусман В. Г. Концепт в системе гуманитарного знания / Зусман В. // Вопросы литературы. - 2003. - № 2. - С. 3-29.

13. Карасик В.И. Культурные доминанты в языке / В.Карасик // Языковая личность: культурные концепты. - Волгоград - Архангельск, 1996. C. 3-16.

14. Маленко С. Феноменологія архетипу в системі соціокультурного освоєння колективного несвідомого (на матеріалах творчості К.Г.Юнга) / С. Маленко. - Автореф. дис. на здобуття наук. ст. канд. філос. наук. - К., 1998. - $18 \mathrm{c}$.

15. Моклиця М. Модернізм у творчості письменників XX ст. / М.Моклиця. Част.1. Українська література. - Луцьк: Вежа, 1999. - 154 с.

16. Петрухіна Л. Образи природи як стани екзистенції у поезії / Людмила Петрухіна. - Автореферат дисертації на здобуття наукового ступеня кандидата філологічних наук. - Львів, 2000. - 20 с.

17. Телия В. Метафора как модель смыслопроизводства и ее экспрессивно-оценочная функция / Вероника Телия // Метафора в языке и тексте : сб. науч. ст. [отв. ред. В. Телия]. - Москва : Наука, 1988. - С. 26-52.

18. Толочин И.В. Метафора и интертекст в англоязычной поэзии / И.Толочин. - С.-Пб.: изд-во С.-Пб. ун-та, 1996. - 96 с. 
19. Юнг К.Г. Алхимия снов; Четыре архетипа: Мать. Дух. Трикстер. Перерождение / К.Г.Юнг. - С.-Пб.: Тимошка, 1997. - 312 с.

В статье рассмотрены некоторые особенности художественной интерпретации архетипов и символов в поэзии Веры Вовк. Одним из источников концептосферы писательницы являются традиционные метаобразы европейской культуры, органично соединенные с образными константами украинского народного творчества. Эти сквозные мотивы лежат в основе общей структуры метаобразов поэзии Веры Вовк и являются маркерами наиболее выразительных черт ее идиостиля. Рассмотренные сквозь призму концептуального анализа различные по мере обобщения символы определяют основные характеристики художественной картины мира лирики Веры Вовк.

Ключевые слова: архетип, символ, конщепт, конщептуальный анализ, художественная картина мира.

The article examines some artistic peculiarities of interpretation of archetypes and symbols in Vira Vovk's poetry. One of the author's sources of concept sphere is traditional European culture meta-images, such as Christian symbols. Those are coherently connected with image constants of Ukrainian folk art. These prevailing motifes are the fundamentals of general meta-images structure in Vira Vovk's poetry; they are markers of the most expressive features of her personal style. The symbols, different by the degree of their generalization, in the light of conceptual analysis have been considered. These symbols determine the main features of theartistic picture of the world in Vira Vovk's lyric poetry.

Key words: archetype, concept, conceptual analysis, artistic picture of the world. 